\author{
E. A. Dolmatova, A. D. Dayanov, T. N. Ostanina \\ Ural Federal University, 28, Mira str., \\ Ekaterinburg, Russia. \\ E-mail:arcfan@yandex.ru
}

\title{
Simulation of an electrolytic bath for electrodeposition of multilayer shielding coatings
}

In this the calculation work galvanic bath of $\mathrm{Cu} /(\mathrm{Ni}+\mathrm{Cu})$ multilayer shielding coatings formation from an acetate electrolyte containing $0,03 \mathrm{~mol} / \mathrm{L}$ of $\mathrm{CuAc}_{2}, 0,3 \mathrm{~mol} / \mathrm{L}$ of $\mathrm{NiAc}_{2}$ and $1,66 \mathrm{~mol} / \mathrm{L}$ of acetic acid were made. According to the results of polarization studies values of coatings deposition pulse mode current density have been chosen and current efficiency of copper and nickel during deposition of $\mathrm{Cu}-\mathrm{Ni}$ alloy has been determined. To ensure a constant formulation of the electrolyte it has been proposed to use insoluble anodes made of stainless steel and continuous circulation of the electrolyte. The scheme of steams enabling the adjustment of the solution formulation with the use of an additional collecting vessel has been developed. The formulation of the correcting stream continuously fed into the collecting vessel has been calculated.

Key words: electrochemistry; simulation; cuprum acetate; nickel acetate; multilayer shielding coatings.

(c) Dolmatova E. A., Dayanov A. D., Ostanina T. N.. 2015

\section{Introduction}

Currently, there is an acute problem of protection devices and the environment from the effects of electromagnetic radiation. To ensure effective protection of the surface of plastics from which basic parts of devices are generally made, it is necessary to apply shielding coating. Multilayer coatings consisting of alternating layers of magnetic (e.g., nickel) and nonmagnetic (e.g., copper) metals are the most effective screens.

As shown by previous studies [1], copper filled composites consisting of an organic polymeric binder and a filler of copper powder can be used to create a conductive basis for a plastic for subsequent deposition of metal coatings. Shielding coatings consisting of alternating layers of copper and nickel, can be obtained by the «single-bath» method [2] from the electrolyte containing cations of the two metals $\mathrm{Cu}^{2+}$ and $\mathrm{Ni}^{2+}$. Conditions for preparing of individual layers are provided with a pulsed electrolysis, in which an alternation of pulses with different values of current takes place. During odd pulses ions of the most electroposi- 
tive nonmagnetic metal (copper) are recovering

$$
\mathrm{Cu}^{2+}+2 \overline{\mathrm{e}} \rightarrow \mathrm{Cu}^{0},
$$

and during the even pulses ions of copper and nickel presented in the electrolyte are discharging to give a magnetic layer, and hydrogen gas is exhaling.

$$
\begin{aligned}
& \mathrm{Cu}^{2+}+2 \overline{\mathrm{e}} \rightarrow \mathrm{Cu}^{0} \\
& \mathrm{Ni}^{2+}+2 \overline{\mathrm{e}} \rightarrow \mathrm{Ni}^{0} \\
& 2 \mathrm{H}^{+}+2 \overline{\mathrm{e}} \rightarrow \mathrm{H}_{2}
\end{aligned}
$$

The purpose of the present work consisted in simulation of a galvanic bath for forming multilayer shielding coatings.

For electrodeposition layered $\mathrm{Cu} /(\mathrm{Ni}+\mathrm{Cu})$ coating acetate electrolyte of the following composition: $0.03 \mathrm{~mol} / \mathrm{L}$ of $\mathrm{CuAc}_{2}, 0,3 \mathrm{~mol} / \mathrm{L}$ of $\mathrm{NiAc}_{2}$ and $1.66 \mathrm{~mol} / \mathrm{L}$ of acetic acid [2] has been used. Monitoring of value $\mathrm{pH}=4.7$ has been periodically conducted.

\section{Experimental part}

To select the parameters of the galvanic bath to be designed experimental studies were conducted.

Polarization measurements were carried out using a ZIVE SP5 electrochemical station with a linear change in the potential in the cell, connected by a threeelectrode circuit.

The potential has been measured with respect to a silver chloride reference electrode.

When dotting the cathodic polarization curve (Fig. 1) the pin type working electrode made of copper wire with a diameter of $2 \mathrm{~mm}$ and a height of $10 \mathrm{~mm}$ has been used. The area on the curve corresponds to the limiting diffusion current of discharge of copper ions, and the subsequent rise of the current corresponds to recovery processes of nickel ions and hydrogen. According to the results of polarization studies current densities: for deposition of copper layer equals to $7 \mathrm{~A} / \mathrm{m}^{2}$ and a magnetic alloy $\mathrm{Ni}-\mathrm{Cu}$ equals to $90 \mathrm{~A} / \mathrm{m}^{2}$ were selected.

The use of soluble anodes will lead to the enrichment of the electrolyte by nickel or copper ions, so it was proposed to use insoluble anodes made of stainless steel 12X18H10T. During polarization studies it was found that anodes made of steel are passivated and not dissolved in the solution.

For technological calculations current efficiency of metal has a great significance. During odd pulses copper recovery with $100 \%$ current efficiency occurs.

To determine the current efficiency of metals during deposition of the magnetic layer experiments on deposition of a $\mathrm{Ni}-\mathrm{Cu}$ coating to sample of stainless steel pre-coated by a copper layer were conducted. At a current density of $90 \mathrm{~A} / \mathrm{m}^{2}$ current efficiency of $\mathrm{Ni}-\mathrm{Cu}$ alloy was $70.6 \%$.

The resulting precipitate of alloy and the copper underlayer have been dissolved in concentrated nitric acid. The concentration of $\mathrm{Ni}^{2+}$ ions in the resulting solution has been determined by photometry allowing estimating the mass of nickel in the alloy. The analysis was

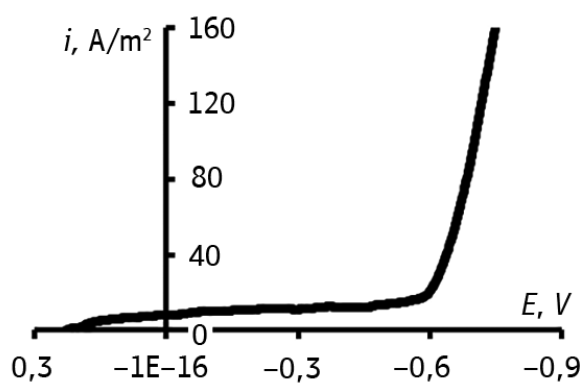

Fig. 1. Cathode polarization curve of the recovery of copper in acetate electrolyte 
conducted by employees of the Department of Analytical Chemistry, CTI, UrFU. From the known weight of the precipitate alloy formulation was calculated as comprising 60 wt. \% of $\mathrm{Ni}$ and $40 \mathrm{wt}$. \% of $\mathrm{Cu}$. The current efficiency of metals has been calculated taking into account proportion of the appropriate metal in the alloy

$$
\begin{aligned}
& B m_{\mathrm{Ni}}=B m_{\text {alloy }} \cdot \omega_{\mathrm{Ni}}=70 \cdot 0,6=42 \%, \\
& B m_{\mathrm{Cu}}=B m_{\text {alloy }} \cdot \omega_{\mathrm{Cu}}=70 \cdot 0,4=28 \% .
\end{aligned}
$$

\section{Discussion of the calculations results}

For the stable operation of the galvanic bath and preparing precipitates of high quality it is necessary to maintain the formulation of the electrolyte unchanged. In the projected bath it can be achieved by adjusting the formulation of continuous circulating flow at the inlet to the bath.

A scheme has been proposed (Fig. 2), which includes a collecting vessel intended for the organization of continuous circulation of the solution and adjusting its formulation. Electrolyte discharged from the bath is divided into two streams, one is directed to the collecting vessel $\left(1 / 2 \vartheta_{1}\right)$, and the second one is directed to neutralize acid excess $\left(1 / 2 \vartheta_{1}\right)$. Simultaneously, correcting stream $\left(\vartheta_{\text {cor }}\right)$ is fed to the collecting vessel, wherein the concentration of copper and nickel acetates is higher than in the bath. The effluent solution from the

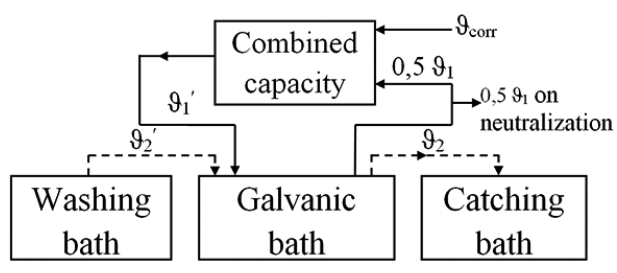

Fig. 2. Correcting streams in the technological scheme of multilayer coating deposition
The summarized reaction occurring during the even pulses based on the current efficiency looks as follows:

$$
\begin{gathered}
\mathrm{BT}_{\mathrm{cu}} \cdot \mathrm{CuAc}+\mathrm{Br}_{\mathrm{Ni}} \cdot \mathrm{NiAc}_{2}+\mathrm{H}_{2} \mathrm{O}= \\
\mathrm{BT}_{\mathrm{cu}} \cdot \mathrm{Cu}+\mathrm{BT}_{\mathrm{Ni}} \cdot \mathrm{Ni}+\left(1-\mathrm{BT}_{\mathrm{Cu}}-\mathrm{BT}_{\mathrm{Ni}}\right) \cdot \mathrm{H}_{2} \uparrow+ \\
+\left(2-1+\mathrm{BT}_{\mathrm{Cu}}+\mathrm{BT}_{\mathrm{Ni}}\right) \cdot \mathrm{HAc}
\end{gathered}
$$

From the latter equation it follows that when using insoluble anodes in the electrolysis process a reduction in the concentration of copper and nickel acetates in a solution will be observed, and the concentration of acetic acid will increase.

collecting vessel is fed into a galvanic bath $\left(\vartheta_{1}^{\prime}\right)$. Furthermore, during the process calculations speed of pseudocontinuous streams $\left(\vartheta^{\prime}\right.$ and $\left.\vartheta_{2}\right)$, which are solutions transferred on details, was considerd.

As the result of the calculation of the stationary mass balance of the galvanic bath it was found that for stable operation it is necessary that the electrolyte is fed to the bath, wherein the acetic acid concentration $\left(\mathrm{C}_{\mathrm{HAc}}^{\prime}=1,48 \mathrm{~mol} / \mathrm{L}\right)$ is below, and the concentrations of copper acetate $\left(\mathrm{C}_{\mathrm{HAc2}}^{\prime}=0,033 \mathrm{~mol} / \mathrm{L}\right)$ and nickel acetate $\left(C_{\mathrm{HAc2}}^{\prime}=0,304 \mathrm{~mol} / \mathrm{L}\right)$ is higher than in the bath. In view of water evaporation rate defined was a volume rate of effluent stream from which then stream feeding to the collecting vessel is formed. While calculating the different values of intensities of components sources in periods of even and odd pulses were taken into account.

The correcting stream is needed to maintain in the collecting vessel a constant formulation of the solution corresponding by components concentrations to a stream directed to the bath of multilayer coating deposition.

Simulation of the stationary mass balance of the collecting vessel has allowed 
determining the rate of the correcting stream and its formulation:

$$
\begin{gathered}
\vartheta_{c o r}=\vartheta_{1}^{\prime}-\frac{\vartheta_{2}}{2}, \\
C_{c o r, i}=\frac{\vartheta_{1}^{\prime} \cdot C_{1 i}^{\prime}-\vartheta_{1} / 2 \cdot C_{1 i}}{\vartheta_{c o r}} .
\end{gathered}
$$

The calculation has showed that the solution containing $1.45 \mathrm{~mol} / \mathrm{L}$ of acetic acid, $0.037 \mathrm{~mol} / \mathrm{L}$ of copper acetate and $0.307 \mathrm{~mol} / \mathrm{L}$ of nickel acetate should be continuously added at a rate equal to $\vartheta_{\text {cor }}=5,0 \cdot 10^{-6} \mathrm{~m}^{3} / \mathrm{s}$ to the collecting vessel.

\section{Conclusion}

During the experimental studies the parameters of pulse mode of multilayer coating deposition, and current efficiency of copper and nickel have been determined.

For preparing layered $\mathrm{Cu} / \mathrm{Cu}-\mathrm{Ni}$ coatings by the single-bath method it has been proposed to use a continuous flow bath with insoluble anodes. The possibility of using stainless steel as an insoluble anode in an acetate electrolyte has been shown.

Using the method of mathematical modeling of mass balances of galvanic baths and the collecting vessel the formulation of the circulating stream incoming to the bath as well as the speed and formulation of the correcting stream incoming to the collecting vessel have been determined.

1. Rudoi V.M. , Ostanina T.N., Darintseva A.B., Ostanin N.I., Alikhanova I. A., Demakov S.L., et al. Electrodeposition of copper on metal-filled composite support. Russian Journal of Electrochemistry. 2010; 46(6):702-706. DOI: 10.1134/ S1023193510060157.

2. Ovchnnikova S. N., Poddubnyi N. P., Masliy A. I., Boldyrev V. V. Schwazacher W. Mutual influence of electrode processes during electrodeposition of layered structures by the single-bath method: The effect of nickel deposition and hydrogen evolution on the transport of copper ions in acetate and sulfamate electrolytes. Russian Journal of Electrochemistry. 2002; 38(11):1210-1206. DOI: 10.1023/A:1021153827310. 
Е. А. Долматова, А. Д. Даянов, Т. Н. Останина

Уральский федеральный университет 620002, Екатеринбург, ул. Мира, 28.

E-mail:arcfan@yandex.ru

\section{Моделирование электролитической ванны нанесения многослойных экранирующих покрытий}

В работе проведен расчет гальванической ванны формирования многослойных экранирующих покрытий $\mathrm{Cu} /(\mathrm{Ni}+\mathrm{Cu})$ из ацетатного электролита, содержащего 0,03 моль/л $\mathrm{CuAc}_{2}$, 0,3 моль/л $\mathrm{NiAc}_{2}$ и 1,66 моль/л уксусной кислоты. По результатам поляризационных исследований выбраны значения плотностей тока импульсного режима нанесения покрытий и определен выход по току меди и никеля в период осаждения сплава Cu-Ni. Для обеспечения постоянного состава электролита предложено использовать нерастворимые аноды из нержавеющей стали и непрерывную циркуляцию электролита. Разработана схема потоков, позволяющая проводить корректировку состава раствора с использованием дополнительной сборной емкости. Рассчитан состав корректирующего потока, непрерывно подаваемого в сборную емкость.

Ключевые слова: электрохимия, моделирование, ацетат меди, ацетат никеля, гальваническая ванна.

(๔ Долматова Е. А., Даянов А.Д., Останина Т. Н., 2015

\section{Введение}

В настоящее время остро стоит проблема защиты приборов и окружающей среды от воздействия электромагнитных излучений. Для обеспечения эффективной защиты на поверхность пластмассы, из которой, как правило, выполнены корпусные детали приборов, необходимо наносить экранирующие покрытия. Наиболее эффективными экранами являются полислойные покрытия, состоящие из чередующихся слоев магнитного (например, никель) и немагнитного (например, медь) металлов.

Как показали проведенные ранее исследования, медьнаполненные композиты, состоящие из органического полимерного связующего и наполнителя медного порошка, можно использовать для создания электропроводной основы на пластмассе с целью последующего нанесения металлических покрытий [1]. Экранирующие покрытия, состоящие из чередующихся слоев меди и никеля, можно получать методом «одной ванны» из электролита, содержащего катионы двух металлов $\mathrm{Cu}^{2+}$ и $\mathrm{Ni}^{2+}$ [2]. Условия для получения 
индивидуальных слоев обеспечиваются импульсным электролизом, в ходе которого происходит чередование импульсов с разными значениями тока. Во время нечетных импульсов восстанавливаются ионы наиболее электроположительного немагнитного металла (медь)

$$
\mathrm{Cu}^{2+}+2 \overline{\mathrm{e}} \rightarrow \mathrm{Cu}^{0},
$$

а во время четных импульсов разряжаются присутствующие в электролите ионы меди и никеля, давая магнитный слой, и выделяется газообразный водород.

\section{Экспериментальная часть}

Для выбора параметров работы проектируемой гальванической ванны были проведены экспериментальные исследования.

Поляризационные измерения проводили с помощью электрохимической станции ZIVE SP5 при линейном изменении потенциала в ячейке, подключенной по трехэлектродной схеме. Потенциал измеряли относительно хлоридсеребряного электрода сравнения.

При съеме катодной поляризационной кривой (рис. 1) использовали рабочий электрод штырькового типа, изготовленный из медной проволоки диаметром 2 мм и высотой 10 мм. Площадка на кривой соответствует предельному диффузионному току разряда ионов меди, а последующий подъем тока - процессам восстановления ионов никеля и водорода. По результатам поляризационных исследований были выбраны плотности тока: для осаждения слоя меди $7 \mathrm{~A} / \mathrm{M}^{2}$ и магнитного сплава $\mathrm{Ni}-\mathrm{Cu}-90 \mathrm{~A} / \mathrm{M}^{2}$.

$$
\begin{aligned}
& \mathrm{Cu}^{2+}+2 \overline{\mathrm{e}} \rightarrow \mathrm{Cu}^{0} \\
& \mathrm{Ni}^{2+}+2 \overline{\mathrm{e}} \rightarrow \mathrm{Ni}^{0} \\
& 2 \mathrm{H}^{+}+2 \overline{\mathrm{e}} \rightarrow \mathrm{H}_{2} .
\end{aligned}
$$

Цель настоящей работы состояла в моделировании гальванической ванны формирования многослойных экранирующих покрытий.

Для электроосаждения слоистых покрытий $\mathrm{Cu} /(\mathrm{Ni}+\mathrm{Cu})$ использовали ацетатный электролит следующего состава: 0,03 моль/л $\mathrm{CuAc}_{2}, 0,3$ моль/л $\mathrm{NiAc}_{2}$ и 1,66 моль/л уксусной кислоты [2]. Периодически проводили контроль величины $\mathrm{pH}=4,7$.

Использование растворимых анодов приведет к обогащению электролита по ионам никеля или меди, поэтому было предложено использовать нерастворимые аноды из нержавеющей стали марки 12X18H10T. В ходе поляризационных исследований было установлено, что аноды из стали в данном растворе пассивируются и не растворяются.

Для проведения технологических расчетов большое значение имеет выход по току металла. Во время нечетных импульсов происходит восстановление меди с выходом по току 100 \%.

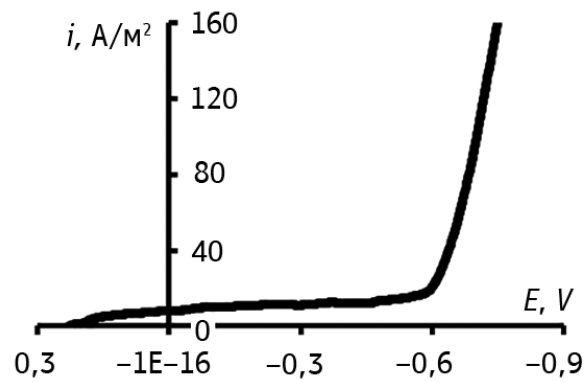

Рис. 1. Катодная поляризационная кривая восстановления меди в ацетатном электролите 
Для определения выхода по току металлов при осаждении магнитного слоя были проведены эксперименты по осаждению покрытия $\mathrm{Ni}-\mathrm{Cu}$ на образец из нержавеющей стали, предварительно покрытий слоем меди. При плотности тока 90 A/м² выход по току сплава $\mathrm{Ni}-\mathrm{Cu}$ составил 70,6 \%.

Полученный осадок сплава и подслой меди растворяли в концентрированной азотной кислоте. Концентрацию ионов $\mathrm{Ni}^{2+}$ в полученном растворе определяли методом фотометрии, что позволило оценить массу никеля в сплаве. Анализ проведен сотрудниками кафедры аналитический химии ХТИ УрФУ. По известной массе осадка рассчитали состав сплава: 60 мас.\% $\mathrm{Ni}$ и 40 мас.\% Cu. Выход по току металлов

\section{Обсуждение результатов расчетов}

Для стабильной работы гальванической ванны и получения осадков высокого качества необходимо поддерживать неизменным состав электролита. В проектируемой ванне этого можно добиться, регулируя состав непрерывного циркуляционного потока на входе в ванну.

Была предложена схема (рис. 2), в которую входит сборная емкость, предназначенная для организации непрерывной циркуляции раствора и корректировкиегосостава. Электролит,

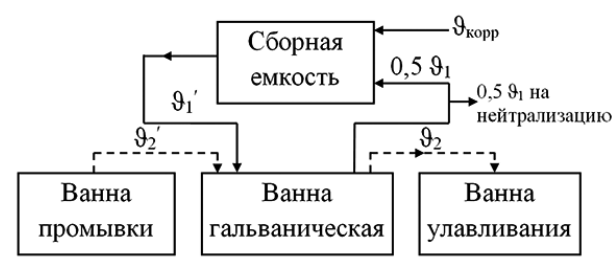

Рис. 2. Корректирующие потоки в технологической схеме нанесения многослойных покрытий считали с учетом доли соответствующего металла в сплаве

$$
\begin{aligned}
& B m_{\mathrm{Ni}}=B m_{\text {alloy }} \cdot \omega_{\mathrm{Ni}}=70 \cdot 0,6=42 \%, \\
& B m_{\mathrm{Cu}}=B m_{\text {alloy }} \cdot \omega_{\mathrm{Cu}}=70 \cdot 0,4=28 \% .
\end{aligned}
$$

Суммарная реакция, протекающая в период четных импульсов, с учетом выходов по току выглядит следующим образом:

$$
\begin{gathered}
\mathrm{BT}_{\mathrm{cu}} \cdot \mathrm{CuAc_{2 }}+\mathrm{BT}_{\mathrm{Ni}} \cdot \mathrm{NiAc}_{2}+\mathrm{H}_{2} \mathrm{O}= \\
\mathrm{BT}_{\mathrm{cu}} \cdot \mathrm{Cu}+\mathrm{BT}_{\mathrm{Ni}} \cdot \mathrm{Ni}+\left(1-\mathrm{BT}_{\mathrm{Cu}}-\mathrm{BT}_{\mathrm{Ni}}\right) \cdot \mathrm{H}_{2} \uparrow+ \\
+\left(2-1+\mathrm{BT}_{\mathrm{Cu}}+\mathrm{BT}_{\mathrm{Ni}}\right) \cdot \mathrm{HAc}
\end{gathered}
$$

Из последнего уравнения следует, что при использовании нерастворимых анодов в процессе электролиза будет наблюдаться уменьшение концентрации ацетатов меди и никеля в растворе, а концентрация уксусной кислоты будет возрастать.

выходящий из ванны, делится на два потока: один направляется в сборную емкость $\left(1 / 2 \vartheta_{1}\right)$, а второй - на нейтрализацию избытка кислоты $\left(1 / 2 \vartheta_{1}\right)$. Одновременно в сборную емкость подается корректировочный поток $\left(9_{\text {корр }}\right)$, в котором концентрация ацетатов меди и никеля выше, чем в ванне. Выходящий из сборной емкости раствор подается в гальваническую ванну $\left(9_{1}^{\prime}\right)$. Кроме того, при проведении технологических расчетов учитывали скорость псевдонепрерывных потоков $\left(9_{1}^{\prime}\right.$ и $\left.\vartheta_{2}\right)$, которые представляют собой растворы, переносимые на деталях.

В результате расчета стационарного материального баланса гальванической ванны было установлено, что для стабильной работы необходимо, чтобы в ванну поступал электролит, в котором концентрация уксусной кислоты $\left(\mathrm{C}_{\text {нАс }}^{\prime}\right.$ $=1,48$ моль/л) ниже, а концентрации 
ацетата меди $\left(\mathrm{C}_{\text {HАс2 }}^{\prime}=0,033\right.$ моль/л) и ацетата никеля $\left(\mathrm{C}_{\mathrm{HAc2}}^{\prime}=0,304\right.$ моль/л) выше, чем в ванне. С учетом интенсивности испарения воды определена объемная скорость выходящего потока, из которого затем формируется поток, поступающий в сборную емкость. При расчете учитывали разные значения интенсивностей источников компонентов в периоды четных и нечетных импульсов.

Корректировочный поток необходим для обеспечения постоянного состава раствора в сборной емкости, соответствующего по концентрациям компонентов потоку, направляемому в ванну нанесения полислойного покрытия.

Моделирование стационарного материального баланса сборной емкости позволило определить скорость корректировочного потока и его состав:

$$
\begin{gathered}
\vartheta_{\text {корр }}=\vartheta_{1}^{\prime}-\frac{\vartheta_{2}}{2}, \\
C_{\text {корр }, i}=\frac{\vartheta_{1}^{\prime} \cdot C_{1 i}^{\prime}-\vartheta_{1} / 2 \cdot C_{1 i}}{\vartheta_{\text {корр }}} .
\end{gathered}
$$

Расчетпоказал,чтовсборнуюемкость необходимо непрерывно добавлять со скоростью $\vartheta_{\text {корр }}=5,0 \cdot 10^{-6} \mathrm{~m}^{3} / \mathrm{c}$ раствор, содержащий 1,45 моль/л уксусной кислоты, 0,037 моль/л ацетата меди и 0,307 моль/л ацетата никеля.

\section{Заключение}

В ходе экспериментальных исследований определены параметры импульсного режима нанесения многослойных покрытий и выходы по току меди и никеля.

Для получения слоистых покрытий $\mathrm{Cu} / \mathrm{Cu}-\mathrm{Ni}$ методом одной ванны предложено использовать проточную ванну с нерастворимыми анодами. Показана возможность использования нержавеющей стали в качестве нераст- воримого анода в ацетатном электролите.

C помощью метода математического моделирования материальных балансов гальванической ванны и сборной емкости определены состав входящего циркуляционного потока в ванну, а также скорость и состав корректирующего потока в сборную емкость.

1. Rudoi V. M., Ostanina T. N., Darintseva A. B., Ostanin N. I., Alikhanova I. A., Demakov S. L., et al. Electrodeposition of copper on metal-filled composite support. Russian Journal of Electrochemistry. 2010; 46(6):702-706. DOI: 10.1134/S1023193510060157. 2. Ovchnnikova S. N., Poddubnyi N. P., Masliy A. I., Boldyrev V. V., Schwazacher W. Mutual influence of electrode processes during electrodeposition of layered structures by the single-bath method: The effect of nickel deposition and hydrogen evolution on the transport of copper ions in acetate and sulfamate electrolytes. Russian Journal of Electrochemistry. 2002; 38(11):1210-1206. DOI: 10.1023/A:1021153827310. 